\title{
High Tolerance of Trichogramma Pretiosum (Hymenoptera: Trichogrammatidae) to the Mixture of the Herbicides Nicosulfuron Plus Atrazine
}

Germano Leão Demolin Leite

Universidade Federal de Minas Gerais

João Marcos Batista Cordeiro

Universidade Federal de Minas Gerais

Leonardo David Tuffi Santos

Universidade Federal de Minas Gerais

Wagner de Souza Tavares ( $\nabla$ wagnermaias@yahoo.com.br)

Asia Pacific Resources International Holdings Ltd. https://orcid.org/0000-0002-8394-6808

Alexandre Igor de Azevedo Pereira

Instituto Federal Goiano

Marcus Alvarenga Soares

Universidade Federal dos Vales do Jequitinhonha e Mucuri

Pedro Guilherme Lemes Alves

Universidade Federal de Minas Gerais

José Eduardo Serrão

Universidade Federal de Vicosa

José Cola Zanuncio

Universidade Federal de Vicosa

Research article

Keywords: Chalcidoidea, Hymenoptera, sulfonylurea, Trichogrammatidae, triazine, weed

Posted Date: May 21st, 2020

DOI: https://doi.org/10.21203/rs.3.rs-30398/v1

License: (c) (i) This work is licensed under a Creative Commons Attribution 4.0 International License.

Read Full License 


\section{Abstract}

Background: Maize, Zea mays (Poaceae), is one of the most important crops in the world, but defoliating caterpillars (Lepidoptera) and weeds can reduce the productivity of this plant. The control of weeds in the maize crop in Brazil is mainly accomplished with nicosulfuron- and atrazine-based herbicides, and of lepidopteran pest eggs with use of several species of Trichogrammatidae (Hymenoptera) parasitoids released. The objective of this study was to evaluate the rates of parasitism and emergence of females and the sex ratio (\%) of 10 Trichogrammatidae species, in a free-choice test, submitted to a mixture of the herbicides Sanson 40 SC $^{\circledR}$ (a.i. nicosulfuron; dose: 30 g.ha $^{-1}$ ) + Gesaprim 500 Ciba-Geigy ${ }^{\circledR}$ (a.i. atrazine; dose: $1500{\mathrm{~g} . h a^{-1}}^{-1}$ in the laboratory.

Results: The parasitism rate (\%) of Trichogramma acacioi Brun, Moraes \& Soares, Trichogrammatoidea annulata de Santis, Trichogramma atopovirilia Oatman \& Platner, Trichogramma bennetti Nagaraja \& Nagarkatti, Trichogramma brunni Nagaraja, Trichogramma brasiliensis Ashmead, Trichogramma demoraesi Nagaraja, Trichogramma galloi Zucchi, and Trichogramma soaresi Nagaraja was lower with the herbicide mixture of nicosulfuron + atrazine than the control and, therefore, this mixture was considered to be slightly harmful (i.e., class II of the International Organization for Biological and Integrated Control) to these parasitoids. This solution reduced the emergence rate (\%) of female $T$. acacioi, T. annulata, T. atopovirilia, T. bruni, T. brasiliensis, T. demoraesi, T. galloi, and T. soaresi, being classified as harmless to $T$. soaresi, moderately harmful to $T$. galloi and slightly harmful to the other species. The herbicide mixture of nicosulfuron + atrazine reduced the sex ratio of $T$. acacioi, $T$. atopovirilia, T. bruni, T. demoraesi, T. galloi, and T. soaresi, being classified as harmless to T. annulata and T. brasiliensis, and slightly harmful to the other species.

Conclusions: The biological parameters (i.e., rates of parasitism and emergence and the sex ratio) of $T$. pretiosum, followed by $T$. bennetti, T. annulata and T. brasiliensis were the least affected by the herbicide mixture. These species should be chosen for release, on pieces of paperboard with parasitized $E$. kuehniella eggs, in crops together with the application of nicosulfuron + atrazine.

\section{Background}

Maize, Zea mays L. (Poales: Poaceae), is a cereal grown worldwide, with low to high technology according to the country [1, 2]. Brazil grows maize on a large scale, mainly for in natura consumption by chickens and use in the manufacture of feed for cattle, horses, fish and pigs [3]. In addition, to a lesser extent, maize is consumed by humans in the form of candies, ice cream, juices and pickles, and in natura as sweet corn $[4,5]$. Weeds can reduce the productivity of this cereal, as reported for the loss of between 10 and $90 \%$ caused by nine weed species in Brazil [6], 17\% in Iran [7] and 21 to $50 \%$ in Pakistan by from 5 to 20 individual plants of the weed Parthenium hysterophorus L. (Asterales: Asteraceae) per square meter [8]. 
The herbicidal a.i. nicosulfuron, from the chemical group sulfonylurea, inhibits the enzyme acetolactate synthase (ALS) in plants and microorganisms by interrupting the biosynthesis of the branched-chain aminoacids (BCAAs) isoleucine, leucine and valine [9]. Thirty-five commercial herbicide formulations containing nicosulfuron as the a.i. are registered in the Brazilian Ministry of Agriculture, Livestock and Food Supply (Ministério da Agricultura, Pecuária e Desenvolvimento - MAPA), including five with nicosulfuron + atrazine and one with nicosulfuron + nicosulfuron [10]. Nicosulfuron is registered for the control of more than 20 species of mono and dicotyledonous weeds in post-emergence in the maize crop in Brazil [10]. Atrazine, from the chemical group triazine, is another herbicidal a.i. with its use permitted in the maize crop in Brazil. Fifty-eight commercial herbicide formulatios with atrazine are registered by MAPA in Brasil, including 22 with atrazine + another a.i. in their formulation [10] to control around 15 species of dicotyledonous weeds in pre- or post-emergence in the maize crop [10]. This active principle inhibits photosystem II, causing irreversible damage to plant cells $[11,12]$. The herbicides nicosulfuron and atrazine are compatible in mixtures, and generally show greater efficiency in weed control when applied together $[13,14]$. These a.i. are selective, with systemic action and toxicological and environmental classifications varying according to the formulation [10].

Biological control agents for insect pests, especially Lepidoptera egg parasitoids such as Trichogramma (Hymenoptera: Trichogrammatidae), can prevent the hatching of caterpillars that damage maize plants, including the fall armyworm, Spodoptera frugiperda (J.E. Smith, 1797) (Lepidoptera: Noctuidae) [15]. These parasitoids use weeds as a hiding place, a source of water and nectar and a place for mating and resting [16]. Weed management by slashing benefits the survival of this pest's natural enemies and protects the soil, but herbicides are used in places with high rates of weed infestation and growth [17]. Herbicides, after direct or indirect contact, can penetrate the cuticle or tegument and reduce parasitism and other biological activities of Trichogramma $[18,19,20]$. The effects of herbicides on Trichogrammatidae vary with the concentration, type of salt and adjuvants in its mixture [21, 22]. The toxicity of pesticides to Trichogrammatidae is generally assessed with the methods recommended by the International Organization for Biological and Integrated Control of Noxious Animals and Plants (IOBC), given to the insects in either free-choice or no-choice feeding in the laboratory [23]. These tests are characterized by treating the host with pesticides during pre- (free-choice) or post-submission (no-choice) to parasitism $[24,25]$.

The objective of this study was to evaluate the rate of parasitism and emergence of females and the sex ratio of 10 Trichogrammatidae species in a free-choice test in the laboratory, after being subjected to a mixture of two herbicide formulations, one based on nicosulfuron and another based on atrazine, registered for use on the maize crop in Brazil.

\section{Results}

\section{Parasitism rate}


The parasitism rate (\%) of the alternative host, the Mediterranean flour moth, Ephestia (= Anagasta) kuehniella Zeller, 1879 (Lepidoptera: Pyralidae) by Trichogramma acacioi Brun, Moraes \& Soares, 1984, Trichogrammatoidea annulata de Santis, 1972, Trichogramma atopovirilia Oatman \& Platner, 1983, Trichogramma bennetti Nagaraja \& Nagarkatti, 1973, Trichogramma bruni Nagaraja, 1983, Trichogramma brasiliensis Ashmead, 1904, Trichogramma demoraesi Nagaraja, 1983, Trichogramma galloi Zucchi, 1988, and Trichogramma soaresi Nagaraja, 1983, was lower with the herbicide solution of nicosulfuron + atrazine than with distilled water (i.e., the control), and that of Trichogramma pretiosum Riley, 1879 , was similar between treatments $(p>0.05)$. The mixture of nicosulfuron + atrazine was classified as slightly harmful (i.e., class II on the toxicity index) to the parasitism rate (\%) for all species of Trichogrammatidae, according to the IOBC classification (Table 1). 
Table 1

Rates of female emergence and parasitism and the sex ratio, reduction (Reduc.) (\%) and classification (Class.) according to the International Organization for Biological and Integrated Control of Noxious Animals and Plants (IOBC) of Trichogrammatoidea annulata and nine species of Trichogramma (Hymenoptera: Trichogrammatidae) with treatments with herbicide solution based on nicosulfuron + atrazine (Nicos. + Atrazine) and in the control with distilled water (Control)

\begin{tabular}{|c|c|c|c|c|c|c|c|c|}
\hline \multirow[b]{2}{*}{ Species } & \multicolumn{2}{|c|}{ Nicos. + Atrazine } & \multicolumn{2}{|l|}{ Control } & \multicolumn{2}{|l|}{ IOBC } & \multicolumn{2}{|c|}{ ANOVA $(g l=9)$} \\
\hline & Mean & SE & Mean & SE & Reduc. & Class. & $\mathrm{F}$ & $\mathrm{p}$ \\
\hline & \multicolumn{8}{|c|}{ Parasitism rate } \\
\hline T. acacioi* & $17.11 \mathrm{~b}$ & 5.21 & $69.63 a$ & 4.70 & 75.4 & II & 45.777 & 0.00000 \\
\hline T. annulata** & $34.67 \mathrm{~b}$ & 6.39 & $58.27 a$ & 3.24 & 40.5 & II & 10.542 & 0.01005 \\
\hline T. atopovirilia** & $16.22 b$ & 7.31 & $39.51 a$ & 2.33 & 58.9 & II & 6.716 & 0.02914 \\
\hline T. bennetti* & $21.46 b$ & 5.41 & $55.56 a$ & 2.45 & 61.4 & II & 33.812 & 0.00025 \\
\hline T. brunik* & $25.11 b$ & 10.04 & $59.68 a$ & 5.05 & 57.9 & II & 7.056 & 0.03264 \\
\hline T. brasiliensis* & $30.67 b$ & 7.73 & $67.50 a$ & 3.62 & 54.6 & II & 14.097 & 0.00559 \\
\hline T. demoraesik* & $15.33 b$ & 8.19 & $48.40 a$ & 8.24 & 68.3 & II & 8.442 & 0.01744 \\
\hline T. galloi*. & $10.22 b$ & 5.25 & $39.85 a$ & 5.13 & 74.4 & II & 23.697 & 0.00089 \\
\hline T. pretiosum ${ }^{\text {n.s. }}$. & $24.00 a$ & 5.47 & $38.52 a$ & 2.74 & 37.7 & II & 5.093 & 0.05044 \\
\hline \multirow[t]{2}{*}{ T. soaresi**. } & $28.00 \mathrm{~b}$ & 8.83 & $44.45 a$ & 3.19 & 37.0 & II & 5.302 & 0.04680 \\
\hline & \multicolumn{8}{|c|}{ Emergence rate } \\
\hline T. acacioi**. & $49.63 b$ & 13.75 & $81.95 a$ & 2.29 & 39.4 & ॥ & 5.375 & 0.04561 \\
\hline T. annulata** & $53.20 \mathrm{~b}$ & 11.06 & $82.54 a$ & 3.84 & 35.5 & II & 5.889 & 0.03819 \\
\hline T. atopovirilia* & $18.05 b$ & 7.95 & $72.84 a$ & 5.27 & 75.2 & II & 23.749 & 0.00088 \\
\hline T. bennetti $i^{\mathrm{n} . \mathrm{s}}$. & $62.96 a$ & 13.90 & $92.49 a$ & 1.63 & 31.9 & ॥ & 4.440 & 0.06438 \\
\hline T. bruni*. & $48.44 b$ & 16.27 & $98.33 a$ & 0.78 & 50.7 & II & 14.239 & 0.00695 \\
\hline T. brasiliensis ${ }^{\star *}$. & $59.48 b$ & 12.02 & $90.33 a$ & 1.01 & 34.2 & II & 6.763 & 0.03158 \\
\hline T. demoraesi* & $22.74 b$ & 11.74 & $93.24 a$ & 2.53 & 75.6 & II & 34.966 & 0.00023 \\
\hline T. galloi*. & $9.41 b$ & 8.40 & $62.22 a$ & 4.81 & 84.9 & III & 18.812 & 0.00189 \\
\hline
\end{tabular}

$\mathrm{SE}=$ standard error of the mean. Averages followed by the same lower letter per line do not differ by the Tukey range test $(*=p<0.01 ; * *=p<0.05) .{ }^{\mathrm{n} . \mathrm{s}} .=$ not significant by ANOVA $(p>0.05)$. Toxicity index: class I = harmless (<30\% reduction), class $I I=$ slightly harmful (30 to $79 \%$ reduction), class III = moderately harmful (80 to $99 \%$ reduction), and class IV = harmful (> $99 \%$ reduction) according to IOBC [23]. 


\begin{tabular}{|c|c|c|c|c|c|c|c|c|}
\hline \multirow[b]{2}{*}{ T. pretiosum ${ }^{\text {n.s }}$. } & \multicolumn{2}{|c|}{ Nicos. + Atrazine } & \multicolumn{2}{|l|}{ Control } & \multicolumn{2}{|l|}{ IOBC } & \multicolumn{2}{|c|}{ ANOVA $(g l=9)$} \\
\hline & $70.00 a$ & 15.27 & $100.00 a$ & 0.00 & 30.0 & II & 3.857 & 0.08113 \\
\hline \multirow[t]{2}{*}{ T. soaresi* } & $75.19 \mathrm{~b}$ & 12.83 & $83.17 a$ & 3.01 & 9.6 & 1 & 10.619 & 0.00986 \\
\hline & \multicolumn{8}{|c|}{ Sex ratio } \\
\hline T. acacioi**. & $0.52 \mathrm{~b}$ & 0.14 & $0.85 a$ & 0.02 & 38.8 & II & 5.209 & 0.04838 \\
\hline T. annulata ${ }^{\text {n.s. }}$. & $0.80 \mathrm{a}$ & 0.13 & $1.00 \mathrm{a}$ & 0.00 & 20.0 & I & 2.250 & 0.16785 \\
\hline T. atopovirilia** & $0.36 b$ & 0.14 & $0.80 a$ & 0.04 & 55.0 & II & 7.715 & 0.02149 \\
\hline T. bennetti ${ }^{\text {n.s. }}$. & $0.70 a$ & 0.15 & $1.00 a$ & 0.00 & 30.0 & II & 3.857 & 0.08113 \\
\hline T. bruni**. & $0.50 \mathrm{~b}$ & 0.16 & $0.99 a$ & 0.01 & 49.5 & II & 10.604 & 0.01393 \\
\hline T. brasiliensis ${ }^{\mathrm{n} . \mathrm{s}}$. & $0.80 a$ & 0.13 & $1.00 \mathrm{a}$ & 0.00 & 20.0 & 1 & 2.286 & 0.16902 \\
\hline T. demoraesi* & $0.30 \mathrm{~b}$ & 0.15 & $1.00 \mathrm{a}$ & 0.00 & 70.0 & II & 21.000 & 0.00132 \\
\hline T. galloi*. & $0.20 \mathrm{~b}$ & 0.13 & $0.91 a$ & 0.02 & 78.0 & II & 30.297 & 0.00038 \\
\hline T. pretiosum ${ }^{\text {n.s. }}$. & $0.70 a$ & 0.15 & $1.00 \mathrm{a}$ & 0.00 & 30.0 & II & 3.857 & 0.08113 \\
\hline T. soaresi** & $0.60 \mathrm{~b}$ & 0.16 & $1.00 \mathrm{a}$ & 0.00 & 40.0 & II & 6.000 & 0.03679 \\
\hline \multicolumn{9}{|c|}{$\begin{array}{l}\mathrm{SE}=\text { standard error of the mean. Averages followed by the same lower letter per line do not differ by } \\
\text { the Tukey range test }(*=p<0.01 ; * *=p<0.05) . \text { n.s }=\text { not significant by ANOVA }(p>0.05) \text {. Toxicity index: } \\
\text { class I = harmless }(<30 \% \text { reduction), class } I I=\text { slightly harmful ( } 30 \text { to } 79 \% \text { reduction), class III = } \\
\text { moderately harmful ( } 80 \text { to } 99 \% \text { reduction), and class IV }=\text { harmful ( }>99 \% \text { reduction) according to IOBC } \\
\text { [23]. }\end{array}$} \\
\hline
\end{tabular}

\section{Emergence Rate}

The emergence rate of females (\%) for T. acacioi, T. annulata, T. atopovirilia, T. bruni, T. brasiliensis, T. demoraesi, T. galloi, and T. soaresi was lower with the herbicide solution of nicosulfuron + atrazine than with distilled water (i.e., the control), and that of T. bennetti and T. pretiosum was similar between the two treatments $(p>0.05)$. The mixture of nicosulfuron + atrazine was classified, according to the IOBC, as harmless to the emergence rate of $T$. soaresi females, slightly harmful to that of $T$. acacioi, $T$. annulata, $T$. atopovirilia, T. bennetti, T. bruni, T. brasiliensis, T. demoraesi, and T. pretiosum and moderately harmful to that of T. galloi (Table 1).

\section{Sex Ratio}


The sex ratio of T. acacioi, T. atopovirilia, T. bruni, T. demoraesi, T. galloi, and T. soaresi was lower with the herbicide mixture of nicosulfuron + atrazine applied to the eggs of the alternative host E. kuehniella than with the control, distilled water, on its own, while that of T. annulata, T. bennetti, T. brasiliensis, and T. pretiosum was similar between the two treatments $(p>0.05)$. This mixture was classified as harmless for the sex ratio of $T$. annulata and $T$. brasiliensis and slightly harmful for the other species, according to the IOBC classification (Table 1).

\section{Discussion}

Brazil uses a large quantity of herbicides based on nicosulfuron and atrazine in the production of maize sold locally as well as for export, although restrictions are reducing or even eliminating the use of these products in certain areas. The expiration of patents has increased the number of commercial herbicide products in Brazil [13, 14, 26, 27], where crop management aims to reduce the amount of a.i. applied per hectare through the use of modern cultivation techniques, including the no-tillage system and transgenic plants [28]. The sugarcane borer, Diatraea saccharalis (F., 1794) (Crambidae), Dichomeris famulata Meyrick, 1914 (Gelechiidae), the corn earworm, Helicoverpa zea (Boddie, 1850) (Noctuidae) and S. frugiperda, are the main lepidopteran defoliators in maize crops in Brazil, and several species of Trichogrammatidae are used in the biological control of their eggs [29]. Herbicide solutions applied to the host eggs pre-parasitism can kill females of these parasitoids before or during oviposition or inhibit oviposition by repelling them. The selectivity of the mixture of the herbicides Sanson 40 SC®) (a.i. nicosulfuron; dose: 30 g.ha ${ }^{-1}$ ) + Gesaprim 500 Ciba-Geigy® (a.i. atrazine; dose: 1500 g.ha ${ }^{-1}$ ) to the emergence rate of adults and the sex ratio of most Trichogrammatidae species evaluated is due to the low penetration rate of these products into the chorion of the host eggs (i.e., E. kuehniella), thus protecting the immature stages of these parasitoids, as reported in a no-choice test in the laboratory in Montes Claros, Minas Gerais state, Brazil [21]. The thick chorion of E. kuehniella eggs (2.63 $\pm 3.23 \mu \mathrm{m})$, with four layers, protects the parasitoids inside, whose resistance increases with their development [30]. In addition, the mixture of Sanson ${ }^{\circledR}$ (a.i. nicosulfuron; concentration: $15.0 \mathrm{~g} . \mathrm{L}^{-1}$ ) + Primóleo® (a.i. atrazine; concentration: 0.3 g. $\mathrm{L}^{-1}$ ) applied to the dorsum of the generalist predator Podisus nigrispinus (Dallas, 1851) (Hemiptera: Pentatomidae) reduced its survival by about $50 \%$ in a laboratory in Diamantina, Minas Gerais state, Brazil [11]. The pesticides can penetrate into the body of this insect, causing deformities, mainly during ecdysis [31]. Pesticides decreased the testicular area and the reproductive potential of surviving Pentatomidae individuals when applied to the dorsum of these insects. The elimination rate of these chemicals, via secretion, was high, but insufficient for reducing their

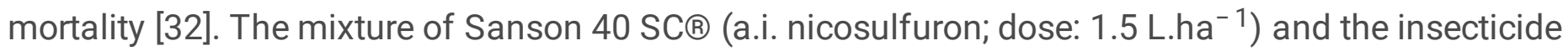
Engeo Pleno® (a.i. $\lambda$-cyhalothrin + thiamethoxam; dose: 0.25 L.ha $^{-1}$ ) reduced the parasitism and emergence rates of $T$. pretiosum in treated eggs of the host E. kuehniella in a no-choice test in a laboratory in Januária, Minas Gerais state, Brazil [25]. This impact may be lower in the field, as this parasitoid hatches in periods during and outside of the planting season, but it needs alternative hosts to survive [33]. 
The similar parasitism rate by $T$. pretiosum between the two treatments shows the resistance of this species, the most distributed and important of its genus in biological control programs in the Americas, where chemicals are widely used [34]. The greater resistance of $T$. pretiosum is also due to its high parasitism capacity in hosts with eggs with different physical characteristics, adaptation to alternative hosts in the absence of preferred ones [35] and survival and reproduction in environments with high temperature variation [36]. In addition, resistance and parasitism by T. pretiosum are higher for well-fed females with larger body sizes [37]. The lower parasitism rate by $T$. acacioi, $T$. annulata, $T$. atopovirilia, $T$. bennetti, T. bruni, T. brasiliensis, T. demoraesi, T. galloi, and T. soaresi with the solution of nicosulfuron + atrazine shows the susceptibility of these species to this herbicide mixture. This low rate suggests female mortality pre-parasitism due to the knockdown effect or inhibition of oviposition due to herbicide repellency. This is suggested by the fact that the parasitism rate by T. atopovirilia $(70.14 \%)$ was higher than that by $T$. pretiosum (29.23\%), with the same number of adults of both species per container competing for $S$. frugiperda eggs, without application of chemicals in the laboratory [38]. The higher parasitism rate by $T$. soaresi than that of $T$. acacioi, in contact with the dry residues of the herbicide solutions Callisto $\circledR^{(a . i . ~ m e s o t r i o n e), ~ E q u i p ~ P l u s ~}{ }^{\circledR}$ (a.i. foramsulfuron + iodosulfuron-methyl), Extrazin $S C \circledast$ (a.i. atrazine + simazine), Primoleo $\circledast$ (a.i. atrazine), Provence 750 WG ${ }^{\circledR}$ (a.i. isoxaflutole) and Siptran 500 SC $\circledast$ (a.i. atrazine) in a laboratory in Pelotas, Rio Grande do Sul state, Brazil, shows the resistance of the first species to these herbicides [39]. This is due to the fact that $T$. acacioi needs a highly favorable environment and maximum vigor of its individuals to exert parasitism because it is more susceptible to pesticides [21, 40, 41, 42] and inadapted to high temperatures [43]. In addition, parasitism by non-fed females is low, producing only males when not mated in the laboratory in Alegre, Espírito Santo state, Brazil [44]. The mixture of two a.i. herbicides can increase the efficiency of the solution for weed control and be less toxic than those with only one a.i. This was shown for the higher adult mortality rate of Trichogramma chilonis Ishii, 1941, exposed to the a.i. insecticides acetamiprid, fipronil or spinetoram (> $95 \%)$ followed by abamectin (71.3-83.5\%), than with mixtures of pyraclostrobin + metiram and trifloxystrobin + tebuconazole $(\leq 36.4 \%)$ in a laboratory in Peshawar, Khyber Pakhtunkhwa, Pakistan [20]. Trichogramma chilonis has good tolerance to pesticides and normal reproductive capacity, mainly because it has two types of parthenogenesis, i.e. arrhenotokous and thelytokous, producing females, males or both sexes with or without reciprocal or backcross mating $[45,46]$. Pesticides applied on Spodoptera eggs can control them or inactivate their natural chemical protection against parasitism by $T$. chilonis [47]. The toxicity of different commercial products with the same a.i. may vary, as reported for the mortality and longevity of $T$. pretiosum adults exposed to maize leaves treated with different commercial products based on glyphosate (i.e. Glyfosato Atanor $48 \circledast$, Gli-Up 480 SL $\circledast$, Roundup Original ${ }^{\circledR}$, Roundup Transorb $\AA$, Roundup WG $\AA$, Shadow 480 SL $\AA$, Stinger $\AA$, and Trop $\AA$ ) in a laboratory in Pelotas, Rio Grande do Sul state, Brazil [48]. This is due to additives, such as the first and third products having 679 and $751 \mathrm{~g} . \mathrm{L}^{-1}$, respectively, of "other ingredients". The type and quantity of toxic salts and adjuvants added to herbicides can increase their toxicity to parasitoids [49]. Herbicide solutions of Alteza 240/30 SL $®$ (a.i. glyphosate + imazetapyr), Gamit 500 EC® (a.i. clomazone), Gliz 480 SL® (a.i. glyphosate), and Roundup Ready 480 SL ${ }^{\circledR}$ (a.i. glyphosate) applied on caterpillars and pupae of $S$. frugiperda were slightly harmful to pupae of the parasitoid Telenomus remus Nixon, 1937 (Hymenoptera: 
Platygastridae) in host eggs, which was attributed to the physical protection to this parasitoid inside them in the laboratory in Rio Verde, Goiás state, Brazil [50]. The chorion of $S$. frugiperda eggs is thick $(2.50-4.40 \mu \mathrm{m})$ and deposited in multiple layers (i.e., generally two or three). Natural enemies can also parasitize those in lower layers, even those covered with thicker hairs deposited by the moth as physical protection [30].

The similar emergence rate of $T$. pretiosum females between the two treatments agrees with that of the oviposition of this natural enemy. Trichogramma pretiosum is tolerant to herbicides and their additives and received a low impact from entomopathogens like Bacillus thuringiensis (Berliner, 1915) var. aizawai, Bacillus thuringiensis var. kurstaki (Bacillales: Bacillaceae), Baculovirus anticarsia (Baculoviridae), Beauveria bassiana (Bals.-Criv.) Vuill. (1912) (Hypocreales: Cordycipitaceae), Metarhizium anisopliae (Metchnikoff) Sorokin (1883) (Hypocreales: Clavicipitaceae), and Trichoderma harzianum Rifai (1969) (Hypocreales: Hypocreaceae) [51]. The lower emergence rate of T. soaresi, T. acacioi, T. annulata, T. atopovirilia, T. bruni, T. brasiliensis, T. demoraesi, and T. galloi females also followed a pattern similar to that of the oviposition for these species, indicating high mortality of immature stages (i.e., larva and/or pupa) of these parasitoids inside the host eggs. The emergence of Trichogrammatidae was also lower in hosts treated with herbicides, such as $T$. bruni, $7.3 \%$ with a Sanson 40 SC $\circledast$ solution (a.i. nicosulfuron; dose: 1.5 L.ha $^{-1}$ ) [41] and T. annulata and T. brasiliensis, $16.2 \%$ and 4.0\%, respectively, with a Gesaprim 500 Ciba Geigy ${ }^{\circledR}$ solution (a.i. atrazine; dose: 150 L.ha $^{-1}$ ) [40], in a no-choice test in the laboratory. The lower emergence rate of Trichogrammatidae females reduces the efficiency of biological control [18, 24]. The emergence rate of $T$. annulata, T. bennetti, T. bruni, T. brasiliensis, T. demoraesi, T. galloi, and $T$. soaresi females, similar between the use of Sanson $40 \mathrm{SC} \circledast$ (a.i. nicosulfurom) and distilled water (i.e., the control) in a no-choice test, was attributed to protection of the parasitoids by the host egg chorion and/or the detoxification capacity of these immature parasitoid stages [41]. However, the highest emergence rate of females for T. acacioi, T. atopovirilia and T. pretiosum, $12.76 \%$, from treated eggs of the alternative host $E$. kuehniella with Sanson $40 \mathrm{SC} \circledast$ (a.i. nicosulfurom) post-parasitism, was due to the hormesis phenomenon [41], when sub-lethal amounts of a stressor (e.g., herbicide) actually benefit an organism [18, 41, 42]. The hormesis phenomenon has also been reported for T. pretiosum, T. acacioi and T. annulata in host eggs treated with Sanson $40 \mathrm{SC} \circledast$ (a.i. nicosulfurom) and for T. pretiosum, $T$. demoraesi, T. galloi, and T. soaresi with Gesaprim 500 Ciba Geigy ${ }^{\circledR}$ (a.i. atrazine), with higher emergence of their females in a no-choice test [40,41]. The higher emergence of females of the pupa parasitoid Palmistichus elaeisis Delvare \& LaSalle, 1993 (Hymenoptera: Eulophidae) with the pre-treatment of the pupae of the host [i.e., the mealworm beetle, Tenebrio molitor L., 1758 (Coleoptera: Tenebrionidae)] with a Scout ${ }^{\circledR}$ solution (a.i. glyphosate; dose: 200 L.ha $^{-1}$ ) in a laboratory in Diamantina, Minas Gerais state, Brazil, was also attributed to hormesis [52]. This parasitoid has a Neotropical distribution, and is common in crops with reduced use of pesticides, such as sugarcane, Saccharum officinarum L. (Poales: Poaceae) and African oil palm, Elaeis guineenses Jacq (Arecales: Arecaceae), and in urban areas with high nonagricultural contaminants like domestic and industrial waste $[52,53,54]$. The reduction in oviposition and emergence rates of Trichogrammatidae females in treatment with herbicide solutions is, in general, 
greater in free-choice tests than in those of no choice, due to the fact that the immature stages have the physical protection of the host eggs in the latter.

The greatest impact of the herbicide mixture on the sex ratio, mainly for T. acacioi, T. atopovirilia, T. bruni, T. demoraesi, T. galloi, and T. soaresi, may have been due to the degeneration (i.e., aminoacid degradation) of both the host eggs and immature stages of these parasitoids [55]. Trichogrammatidae females are larger than males, and lay female eggs in bigger hosts and male eggs in smaller ones [56]. The larger size of the host eggs, usually containing female insects, increases the contact and absorption of a higher volume of herbicide. The reduction in the sex ratio of these parasitoids may also be due to the fact that some Trichogrammatidae species require a larger number of fertile females and that their first eggs are deposited in host eggs originating females [57]. The chemical composition of the eggshell and the liquid inside the host eggs also affects the impact of pesticides on the parasitoids inside them [30]. The sex ratio of $T$. annulata, $T$. bennetti, $T$. brasiliensis, and $T$. pretiosum, similar between the two treatments, corresponds to the fact that these species have a wide geographical distribution and are common in crops with the application of different pesticides [58], especially the first, which has better biological parameters than the other species of Trichogramma [59]. The mixture of Sanson 40 SC $\circledast$ (a.i. nicosulfuron) + Gesaprim 500 Ciba-Geigy ${ }^{\circledR}$ (a.i. atrazine) reduced the sex ratio of $T$. bennetti by $3 \%$ and that of T. galloi and T. pretiosum by $2 \%$ [21], Gesaprim 500 Ciba Geigy ${ }^{\circledR}$ alone reduced that of T. bruni by $66.7 \%, T$. atopovirilia by $17.5 \%$ and $T$. bennettii by $15.0 \%$ [40], and Sanson 40 SC $\circledast$ alone reduced that of T. galloi by $6.0 \%$, T. bennettii by $4.0 \%$ and $T$. pretiosum by $2.0 \%$ [41] in no-choice tests. The reproduction potential of parasitoids of the families Eulophidae and Trichogrammatidae is high, but it has been reduced by the application of herbicides $[60,61]$. The mixture of Sanson 40 SC $\circledast$ (a.i. nicosulfuron) + Gesaprim 500 Ciba-Geigy ${ }^{\circledR}$ (a.i. atrazine) in no-choice tests reduced the sex ratio of $T$. brasiliensis by $5.49 \%$ and that of T. atopovirilia by 5.83\% [21], Gesaprim 500 Ciba Geigy ${ }^{\circledR}$ (a.i. atrazine) alone reduced that of $T$. acacioi by $-4.8 \%, T$. brasiliensis by $-4.4 \%, T$. annulata and $T$. galloi by $0.0 \%$ and $T$. pretiosum by $1.0 \%$ [40], and Sanson $40 \mathrm{SC} \otimes$ (a.i. nicosulfuron) alone reduced that of $T$. atopovirilia by $3.9 \%$ [41].

\section{Conclusions}

The herbicide mixture of nicosulfuron + atrazine was more selective (i.e., caused lower reductions in rates of parasitism and emergence and the sex ratio) for T. pretiosum, followed by $T$. bennetti, T. annulata, and $T$. brasiliensis. These species should be selected for release, on paperboards with parasitized $E$. kuehniella eggs, in maize crops with the application of nicosulfuron + atrazine.

\section{Methods}

\section{Experimental site}

The insects were reared and the experiment developed in a room at $25 \pm 4^{\circ} \mathrm{C}$ and $70 \pm 10 \% \mathrm{RH}$, under a 12:12 (L:D) h photoperiod, at the George Washington Gomez de Moraes Insectary of the Institute of 


\section{Rearing of Trichogrammatidae and its alternative host, $E$. kuehniella}

The 10 Trichogrammatidae species were obtained from the ICA/UFMG Insectary where they have been reared for about 40 years, nine of which are of the genus Trichogramma (T. acacioi, T. atopovirilia, T. bennetti, T. brasiliensis, T. brunni, T. demoraesi, T. galloi, T. pretiosum, and T. soaresi) and one of the genus Trichogrammatoidea ( $T$. annulata). Trichogrammatidae were first collected in Brazil and identified in the $70 \mathrm{~s}$ and $80 \mathrm{~s}$ by Dr. George Washington Gomez de Moraes. Species identification was reviewed in the 2000 s by Dr. Ranyse Barbosa Querino (EMBRAPA Roraima, Boa Vista, Roraima state, Brazil) and Dr. José Roberto Postali Parra (University of São Paulo, Piracicaba, São Paulo state, Brazil).

Colonies of parasitoids are kept in $500 \mathrm{~mL}$ glass jars with the opening closed with polyvinyl chloride (PVC) plastic film $[24,62]$. Trichogrammatidae are collected from field crops, and new individuals are added to the laboratory colonies every six months [24].

Ephestia kuehniella eggs, an insect pest of stored products and sub-products $[63,64,65]$, are used as an alternative host for parasitoids [24]. Immature stages of E. kuehniella are reared on a diet consisting of wheat bran, Triticum aestivum L. (Poales: Poaceae) and cornmeal in a 48.5:48.5\% proportion with $3 \%$ beer yeast [41]. The ingredients are homogenized in a $5 \mathrm{~L}$ plastic bucket and the mixture placed in plastic pots ( $25 \mathrm{~cm}$ diameter $\times 10 \mathrm{~cm}$ high), closed with a plastic lid with a hole covered with organza fabric for aeration and compacted in the pots using a wooden spatula.

Ephestia kuehniella adults, immediately after emergence, are transferred to plastic cages $(24 \mathrm{~cm}$ high $\times$ $12 \mathrm{~cm}$ diameter) with the upper opening covered with organza fabric and the base opening placed on a plastic plate, for mating and egg deposition [40]. Ephestia kuehniella moths are collected every six months in warehouses to add new individuals to the laboratory colony [24].

\section{Preparation Of Trichogrammatidae Paperboards}

Ephestia kuehniella eggs were collected every $12 \mathrm{~h}$, and impurities such as dust and scales from moths were separated manually with cotton wool [24]. These eggs were placed in $50 \mathrm{~mL}$ plastic cups and glued in a layer on white paperboard pieces $(0.5 \mathrm{~cm}$ wide $\times 5.0 \mathrm{~cm}$ long) with non-toxic Arabic gum diluted to $10 \%$ in distilled water. The embryos in the eggs were inviabilized by exposing the paperboards to germicidal ultraviolet (UV) light for an hour and a half in a UV light chamber [41].

\section{Experimental Design}


The impact of the mixed commercial herbicide products, Sanson 40 SC $®$ (i.e., nicosulfuron) and Gesaprim 500 Ciba-Geigy ${ }^{\circledR}$ (i.e., atrazine), was evaluated on 10 Trichogrammatidae species in a freechoice test. Nicosulfuron and atrazine were chosen because they have been two of the most widely used a.i. in the maize crop in the American continent for decades.

The design was entirely randomized, with 10 Trichogrammatidae species and the mixture of the herbicides based on nicosulfuron and atrazine. The control was distilled water by itself. The experimental plot consisted of a piece of white paperboard $(0.5 \mathrm{~cm}$ wide $\times 5.0 \mathrm{~cm}$ long) with approximately $45 E$. kuehniella eggs ( $<24 \mathrm{~h}$ after being laid) each, with a total of 200 replications (200 pieces of paperboard).

Each piece of paperboard was subjected to one of two treatments, which consisted of the solution of the homogenized mixture of Sanson $40 \mathrm{SC}{ }^{\circledR}$ (a.i. nicosulfuron: $30 \mathrm{~g}$.ha ${ }^{-1}, 0.06 \mu \mathrm{g} . \mathrm{cm}^{-2}$ of the commercial product or $0.03 \mu \mathrm{g} . \mathrm{cm}^{-2}$ of the a.i. per paperboard) + Gesaprim 500 Ciba-Geigy ${ }^{\circledR}$ (a.i. atrazine: $1500 \mathrm{~g} . \mathrm{ha}^{-1}, 0,03 \mu \mathrm{L} . \mathrm{cm}^{-2}$ of the commercial product or $0,015 \mu \mathrm{g} . \mathrm{cm}^{-2}$ of a.i. per paperboard), or the control, consisting of distilled water. The dosages used in the mixture of these herbicides were those recommended by the manufacturers for the maize crop in Brazil, according to MAPA. The herbicide solution and distilled water were applied to the pieces of paperboard with E. kuehniella eggs using a Guarany ${ }^{\circledR}$ hand sprayer (Itú, São Paulo state, Brazil) with a capacity of $580 \mathrm{~mL}$. The volume of liquid released by the manual sprayer was measured, and its conformity was evaluated according to norms of the National Institute of Metrology, Quality and Technology (Instituto Nacional de Metrologia, Qualidade e Tecnologia - INMETRO) of the Ministry of Development, Industry and Foreign Trade (Ministério do Desenvolvimento, Indústria e Comércio Exterior-MDIC) of Brazil. The hand sprayer was tested three times (3 replications) in a pre-use calibration process for $30 \mathrm{~min}$. $\left(16.73 \times 10^{-2} \pm 0.01 \mathrm{mg}\right.$ of herbicide solution per piece of paperboard) $[39,66]$. After spraying, the pieces of paperboard were allowed to dry for an hour without being exposed to direct sunlight in order to evaporate excess water [67].

After this evaporation stage, each piece of paperboard was inserted into a glass test tube $(9.0 \mathrm{~cm}$ high $\times$ $1.0 \mathrm{~cm}$ diameter) with a newly-emerged female of the parasitoid ( $<24 \mathrm{~h}$ after hatched). The tube opening was closed with PVC plastic film and kept in an aclimatized room. Parasitism was allowed until the death of the Trichogrammatidae female, which occurred, on average, six days after their introduction into the tubes. Those who died early (< two days) were replaced. The mating of Trichogrammatidae females is not necessary, as they reproduce by parthenogenesis [68].

\section{Assessments}

The rates of parasitism and emergence of male and female Trichogrammatidae, and the sex ratio between them (\%), were evaluated. Parasitized eggs were those which blackened about four days after the beginning of their submission to parasitism. Male and female Trichogrammatidae were identified by the dimorphism of their antennae, feathery in males and nailed in females $[69,70]$. The sex ratio was 
calculated using the proportion of males to females, with the formula: [number of females $\div$ (number of males + number of females) $] \times 100[29,41,71]$.

The nicosulfuron + atrazine solution was classified according to the reduction of the rates of parasitism and female emergence and the sex ratio (\%) of the Trichogrammatidae, as: $1=$ harmless $(<30 \%$ reduction); 2 = slightly harmful (between 30 to $79 \%$ reduction); 3 = moderately harmful (between 80 to $99 \%$ reduction); $4=$ harmful (>99\% reduction), as described by the IOBC [23]. The reduction in parasitism and emergence rates of females was calculated with the equation: $\%$ reduction $=100-$ average $[\%$ average treatment with herbicide $\div \%$ average treatment control) $\times 100][66,72]$.

Statistical analyses were performed using the SAEG System for Statistical Analysis (Sistema para Análises Estatísticas) software from the Federal University of Viçosa (Universidade Federal de Viçosa) [73]. Data on rates of female parasitism and emergence and the sex ratio (\%) were transformed into arcsine [74] and submitted to analysis of variance (one-way ANOVA), and the means were compared by the Tukey range test [75], both for $p<0.01$ and $p<0.05$.

\section{Abbreviations}

a.i.

active ingredient

\section{Declarations}

\section{Acknowledgment}

David Michael Miller, a professional editor and proofreader and native English speaker, has reviewed and edited this manuscript for grammar, punctuation, readability, spelling, structure, and word choice.

\section{Authors' contributions}

GLDL, LDTS, JES, and JCZ were responsible for funding acquisition and conceiving the project. JMBC, W de ST, AI de AP, MAS, and PGLA ran insect rearing and herbicide solution preparation. JMBC, W de ST, Al de AP, MAS, and PGLA conducted assessments and laboratory data collection. GLDL, JMBC, W de ST, and JCZ conducted data analysis and visual presentation. GLDL, JMBC, W de ST, and JCZ wrote the manuscript. All authors read and approved the final manuscript.

\section{Funding}

The research received grants from the following Brazilian institutions: Conselho Nacional de Desenvolvimento Científico e Tecnológico (CNPq), Coordenação de Aperfeiçoamento de Pessoal de Nível Superior (CAPES), Fundação de Amparo à Pesquisa do Estado de Minas Gerais (FAPEMIG), and 


\section{Availability of data and materials}

All results are included in the article.

\section{Ethics approval and consent to participate}

Not applicable.

\section{Consent for publication}

Not applicable.

\section{Competing interests}

The authors declare that they have no competing interests.

\section{Author details}

${ }^{1}$ Insetário G.W.G. de Moraes, Instituto de Ciências Agrárias, Universidade Federal de Minas Gerais, 39404006, Montes Claros, Minas Gerais, Brasil. E-mails: germano.demolin@gmail.com, jmarcosb12@hotmail.com, Ituffi@ufmg.br, pedroglemes@ufmg.br ${ }^{2}$ Asia Pacific Resources International Holdings Ltd. (APRIL), Riau Andalan Pulp and Paper (RAPP), 28300, Pangkalan Kerinci, Riau, Sumatra, Indonesia. E-mail: wagnermaias@yahoo.com.br ${ }^{3}$ Departamento de Agronomia, Instituto Federal GoianoCampus Urutaí, 75790-000, Urutaí, Goiás, Brasil. E-mail: alexandre.pereira@ifgoiano.edu.br ${ }^{4}$ Programa de Pós-Graduação em Produção Vegetal, Universidade Federal dos Vales do Jequitinhonha e Mucuri, 39100 000, Diamantina, Minas Gerais, Brasil. E-mail: marcusasoares@yahoo.com.br ${ }^{5}$ Departamento de Biologia Geral, Universidade Federal de Viçosa, 36570-900, Viçosa, Minas Gerais, Brasil. E-mail: jeserrao@ufv.br ${ }^{6}$ Departamento de Entomologia/BIOAGRO, Universidade Federal de Viçosa, 36570-900, Viçosa, Minas Gerais, Brasil. E-mail: zanuncio@ufv.br

\section{References}

1. Rao NV, Jain PK, Kumar NK, et al. Adoption of maize (Zea mays L) production technologies in Karimnagar District of Telangana. J Krishi Vigyan. 2017;5:1-4. http://dx.doi.org/10.5958/23494433.2017.00001.0. 
2. Meena ML, Dudi A. Growth parameters and yield of maize varieties (Zea mays L.) in Tribal Hills Area of Pali District, Rajasthan, India. Int J Curr Microbiol App Sci. 2018;7:2319-28. https://doi.org/10.20546/ijcmas.2018.704.266.

3. Neumann $M$, Horst EH, Dochwat $A$, et al. Performance and carcass traits of calves fed with different hybrids of corn silage. Agrarian. 2018;11:50-8. https://doi.org/10.30612/agrarian.v11i39.6693.

4. Costa FR, Damaso LF, Mendes RC, et al. Performance of corn hybrids grown under different levels of nitrogen and for in natura consumption. Científica. 2015;43:109-16. http://dx.doi.org/10.15361/1984-5529.2015v43n2p109-116.

5. Favarato LF, de Souza JL, Galvão JCC, et al. Qualitative attributes and postharvest conservation of green ears of maize grown on different cover crops in organic no-till system. Rev Ceres. 2016;63:532-7. http://dx.doi.org/10.1590/0034-737X201663040014.

6. Kozlowski LA, Koehler HS, Pitelli RA. Times and extension of weed coexistence period of weeds interfering in corn (Zea mays) yield. Planta Daninha. 2009;27:481-90. http://dx.doi.org/10.1590/S0100-83582009000300008.

7. Amini R, Abdi H, Nassab ADM. Effect of integrated weed management methods on yield and yield components of corn (Zea mays L.) in Kermanshah Province, Iran. J Plant Prot (Agr Sci Tech). 2017;31:92-104.

8. Safdar ME, Tanveer A, Khaliq A, et al. Yield losses in maize (Zea mays) infested with parthenium weed (Parthenium hysterophorus L.). Crop Prot. 2015;70:77-82. https://doi.org/10.1016/j.cropro.2015.01.010.

9. Duggleby RG, McCourt JA, Guddat LW. Structure and mechanism of inhibition of plant acetohydroxyacid synthase. Plant Physiol Biochem. 2008;46:309-24. https://doi.org/10.1016/j.plaphy.2007.12.004.

10. AGROFIT (Sistemas de Agrotóxicos Fitossanitários). Ministério da Agricultura, Pecuária e Abastecimento (MAPA) do Brasil. Disponível em http://agrofit. agricultura.gov.br/agrofit_cons/principal_agrofit_cons (Acessado em 15 de janeiro de 2020).

11. Menezes CWG, Santos JB, Assis Júnior SL, et al. Selectivity of atrazin and nicosulfurom to Podisus nigrispinus (Heteroptera: Pentatomidae). Planta Daninha. 2012;30:327-34. http://dx.doi.org/10.1590/S0100-83582012000200011.

12. Kumar V, Kumar V, Upadhyay N, et al. Chemical, biochemical and environmental aspects of atrazine. J Bio Env Sci. 2014;5:149-65.

13. Chen $Y$, Yang Y, Zhou J, et al. Effects of different herbicides on maize growth and weed control in maize fields. Agr Sci Tech. 2017;18:1738-40.

14. Giraldeli AL, da Silva GS, Silva AFM, et al. Efficacy and selectivity of alternative herbicides to glyphosate on maize. Rev Ceres. 2019;66:279-86. http://dx.doi.org/10.1590/0034737x201966040006.

15. Shylesha AN, Jalali SK, Gupta A, et al. Studies on new invasive pest Spodoptera frugiperda (J. E. Smith) (Lepidoptera: Noctuidae) and its natural enemies. J Biol Control. 2018;32:145-51. 
https://doi.org/10.18311/jbc/2018/21707.

16. Cheng $S$, Lin R, Wang $L$, et al. Comparative susceptibility of thirteen selected pesticides to three different insect egg parasitoid Trichogramma species. Ecotox Environ Safe. 2018;166:86-91. https://doi.org/10.1016/j.ecoenv.2018.09.050.

17. Fontem LA, Chikoye D. Efficacy of herbicide formulations for weed control in maize in a humid tropical environment. J Food Agric Environ. 2012;10:1572-4.

https://doi.org/10.1016/j.cropro.2010.06.011.

18. Khan MA, Khan H, Ruberson JR. Lethal and behavioral effects of selected novel pesticides on adults of Trichogramma pretiosum (Hymenoptera: Trichogrammatidae). Pest Manag Sci. 2015;71:1640-8. https://doi.org/10.1002/ps.3972.

19. Khan MA, Ruberson JR. Lethal effects of selected novel pesticides on immature stages of Trichogramma pretiosum (Hymenoptera: Trichogrammatidae). Pest Manag Sci. 2017;73:2465-72. https://doi.org/10.1002/ps.4639.

20. Khan MA. Lethal and parasitism effects of selected novel pesticides on adult Trichogramma chilonis (Hymenoptera: Trichogrammatidae). J Plant Dis Protect. 2020;127:81-90. https://doi.org/10.1007/s41348-019-00280-2.

21. Leite GLD, de Paulo PD, Zanuncio JC, et al. Nicosulfuron plus atrazine herbicides and Trichogrammatidae (Hymenoptera) in no-choice test: selectivity and hormesis. Bull Environ Contam Toxicol. 2017;99:589-94. https://doi.org/10.1007/s00128-017-2174-7.

22. Valente ECN, Broglio SMF, Dias-Pini N da. S, et al. Selectivity of pesticides to egg parasitoid in sugarcane. Sugar Tech. 2018;20:765-9. https://doi.org/10.1007/s12355-018-0605-3.

23. Sterk G, Hassan SA, Baillod M, et al. Results of the seventh joint pesticide testing programme carried out by the IOBC/WPRS-Working Group 'Pesticides and Beneficial Organisms'. Biocontrol. 1999;44:99-117. https://doi.org/10.1023/A:1009959009802.

24. Pontes JP, Leite GLD, Bispo EPR, et al. A glyphosate-based herbicide in a free-choice test on parasitism, emergence, and female-biased sex ratio of 10 Trichogrammatidae. J Plant Dis Protect. 2019;129:73-9. https://doi.org/10.1007/s41348-019-00277-x.

25. dos Santos TP, de Menezes CWG, Batista CH, et al. Selectivity of registered pesticides for the corn crop on immature stages of Trichogramma pretiosum (Hymenoptera: Trichogrammatidae). Ciênc Agrotec. 2019;43:e020719. http://dx.doi.org/10.1590/1413-7054201943020719.

26. 10.1590/1806-90882018000100007

Carvalho GP, Erasmo EAL, Reis MR, Silva GH, Silva AA, Alves PCMS. Growth analysis of hybrid Eucalyptus urograndis (E. grandis $\times$ E. urophylla) in response to simulated drift of auxinic herbicides. Rev Árvore. 2018;42:e420107. http://dx.doi.org/10.1590/1806-90882018000100007.

27. Duke SO, Powles SB, Sammons RD. Glyphosate - how it became a once in a hundred year herbicide and its future. Outlooks Pest Manag. 2018;29:247-51. https://doi.org/10.1564/v29_dec_03.

28. Ferreira AC, de B, Bogiani, Sofiatti JC. V, et al. Chemical control of stalk regrowth in glyphosateresistant transgenic cotton. Rev Bras Eng Agríc Ambient. 2018;22:530-4. 
http://dx.doi.org/10.1590/1807-1929/agriambi.v22n8p530-534.

29. de Souza AR, Giustolin TA, Querino RB, et al. Natural parasitism of lepidopteran eggs by Trichogramma species (Hymenoptera: Trichogrammatidae) in agricultural crops in Minas Gerais, Brazil. Fla Entomol. 2016;99:221-5. https://doi.org/10.1653/024.099.0210.

30. Cônsoli FL, Kitajima EW, Parra JRP. Ultrastructure of the natural and factitious host eggs of Trichogramma galloi Zucchi and Trichogramma pretiosum Riley (Hymenoptera:

Trichogrammatidae). Int J Insect Morphol Embryol. 1999;28:211-31.

https://doi.org/10.1016/S0020-7322(99)00026-4.

31. de Clercq P, de Cock A, Tirry L, et al. Toxicity of diflubenzuron and pyriproxyfen to the predatory bug Podisus maculiventris. Entomol Exp Appl. 1995;74:17-22. https://doi.org/10.1111/j.15707458.1995.tb01870.x.

32. Cremonez PSG, Gouvea SP, Pinheiro DO, et al. Chitin biosynthesis inhibitors in Euschistus heros Fabr. (Hemiptera: Pentatomidae): morphometric alterations in testes and nuclei of testicular accessory cells of adults. J Agric Sci. 2019;11:410-7. https://doi.org/10.5539/jas.v11n1p410.

33. Foerster MR, Machioro CA, Foerster LA. How Trichogramma survives during soybean offseason in Southern Brazil and the implications for its success as a biocontrol agente. Biocontrol. 2015;60:111. https://doi.org/10.1007/s10526-014-9616-5.

34. Pinto JD, Oatman ER, Platner GR. Trichogramma pretiosum and a new cryptic species occurring sympatrically in Southwestern North America (Hymenoptera: Trichogrammatidae). Ann Entomol Soc Am. 1986;79:1019-28. https://doi.org/10. 1093/aesa/79.6.1019.

35. Brotodjojo RRR, Walter GH. Oviposition and reproductive performance of a generalist parasitoid (Trichogramma pretiosum) exposed to host species that differ in their physical characteristics. Biol Control. 2006;39:300-12. https://doi.org/10.1016/j.biocontrol.2006.08.011.

36. Zuim V, Rodrigues HS, Pratissoli D, et al. Thermal requirements and performance of the parasitoid Trichogramma pretiosum (Hymenoptera: Trichogrammatidae) on Helicoverpa armigera (Lepidoptera: Noctuidae) eggs under variable temperatures. Ecol Entomol. 2017;46:1156-64. https://doi.org/10.1093/ee/nvx132.

37. Kazmer DJ, Luck RF. Field tests of the size-fitness hypothesis in the egg parasitoid Trichogramma pretiosum. Ecology. 1995;76:412-25. https://doi.org/10.2307/1941200.

38. Jaraleño-Teniente J, Lomeli-Flores JR, Rodríguez-Leyva E, et al. Egg parasitoids survey of Spodoptera frugiperda (Smith) (Lepidoptera: Noctuidae) in maize and sorghum in Central Mexico. Insects. 2020;11:157. https://doi.org/10.3390/insects11030157.

39. Stefanello Júnior GJ, Grützmacher AD, Grützmacher DD, et al. Selectivity of herbicides registered on corn to Trichogramma pretiosum (Hymenoptera: Trichogrammatidae). Planta Daninha. 2008;26:343-51. http://dx.doi.org/10.1590/S0100-83582008000200010.

40. Leite GLD, de Paulo PD, Zanuncio JC, et al. Effects of atrazine-based herbicide on emergence and sex ratio of Trichogrammatidae (Hymenoptera). Fla Entomol. 2015;98:899-902. https://doi.org/10.1653/024.098.0313. 
41. Leite GLD, de Paulo PD, Zanuncio JC, et al. Herbicide toxicity, selectivity and hormesis of nicosulfuron on 10 Trichogrammatidae (Hymenoptera) species parasitizing Anagasta (= Ephestia) kuehniella (Lepidoptera: Pyralidae) eggs. J Environ Sci Health B. 2017;52:70-6. https://doi.org/10.1080/03601234.2016.1229476.

42. Leite GLD, Paulo PD, Tuffi-Santos LD, et al. Efficacy of Trichogrammatidae species (Hymenoptera) submitted to the herbicide glyphosate. Planta Daninha. 2019;37:e019216439. http://dx.doi.org/10.1590/s0100-83582019370100147.

43. Pratissoli D, Bueno A, de F, Bueno RCO de. F, et al. Trichogramma acacioi (Hymenoptera, Trichogrammatidae) parasitism capacity at different temperatures and factitious hosts. Rev Bras Entomol. 2009;53:151-3. https://doi.org/10.1590/S0085-56262009000100032.

44. Pratissoli D, de Oliveira HN, Polanczyk RA, et al. Adult feeding and mating effects on the biological potential and parasitism of Trichogramma pretiosum and T. acacioi (Hym.: Trichogrammatidae). Braz Arch Biol Technol. 2009;52:1057-62. https://doi.org/10.1590/S1516-89132009000500001.

45. Chen B-h, Kfir R, Chen CN. The thelytokous Trichogramma chilonis in Taiwan. Entomol Exp Appl. 1992;65:187-94. https://doi.org/10.1111/j.1570-7458.1992.tb01642.x.

46. Jalali SK, Singh SP, Venkatesan T, et al. Development of endosulfan tolerant strain of an egg parasitoid Trichogramma chilonis Ishii (Hymenoptera: Trichogrammatidae). Indian J Exp Biol. 2006;44:584-90.

47. Ohta I, Kazuki M, Kobayashi M. Effect of the scale-hair of the common cutworm egg mass on the oviposition behavior of Trichogramma chilonis Ishii (Hymenoptera: Trichogrammatidae). Appl Entomol Zool. 1994;29:608-9. https://doi.org/10.1303/aez.29.608.

48. Pasini RA, Grützmacher AD, Spagnol D, et al. Persistence of desiccant herbicides applied to transgenic maize on Trichogramma pretiosum Riley, 1879 (Hymenoptera: Trichogrammatidae). Rev Ciênc Agron. 2017;48:175-81. https://doi.org/10.5935/1806-6690.20170020.

49. Bastos CS, de Almeida RP, Suinaga FA. Selectivity of pesticides used on cotton (Gossypium hirsutum) to Trichogramma pretiosum reared on two laboratory-reared hosts. Pest Manag Sci. 2006;62:91-8. https://doi.org/10.1002/ps.1140.

50. do Carmo EL, Bueno AF, Bueno RCOF, et al. Selectivity of pesticides used in soybean crops to Trichogramma pretiosum Riley, 1879 (Hymenoptera: Trichogrammatidae) pupae. Arq Inst Biol. 2010;77:283-90.

51. Amaro JT, Bueno AF, Pomari-Fernandes AF, et al. Selectivity of organic products to Trichogramma pretiosum Riley (Hymenoptera: Trichogrammatidae). Neotrop Entomol. 2015;44:489-97. https://doi.org/10.1007/s13744-015-0317-2.

52. Menezes CWD, Soares MA, Santos JB, et al. Reproductive and toxicological impacts of herbicides used in Eucalyptus culture in Brazil on the parasitoid Palmistichus elaeisis (Hymenoptera: Eulophidae). Weed Res. 2012;52:520-5. https://doi.org/ 10.1111/j.1365-3180.2012.00938.x.

53. Tavares W, de S, Zanuncio, Hansson TV. C, et al. Emergence of Palmistichus elaeisis (Hymenoptera: Eulophidae) from pupae of Thagona tibialis (Lepidoptera: Lymantriidae) collected in the medicinal 
plant Terminalia catappa (Combretaceae). Entomol News. 2012;122:250-6.

https://doi.org/10.3157/021.122.0306.

54. Alcántara-de la Cruz R, Zanuncio JC, Lacerda MC, et al. Side-effects of pesticides on the generalist endoparasitoid Palmistichus elaeisis (Hymenoptera: Eulophidae). Sci Rep. 2017;7:10064. https://doi.org/10.1038/s41598-017-10462-3.

55. 10.1007/s10646-011-0704-3

Saber M. Acute and population level toxicity of imidacloprid and fenpyroximate on an important egg parasitoid, Trichogramma cacoeciae (Hymenoptera: Trichogrammatidae). Ecotoxicology. 2011;20:1476-1484. https://doi.org/10.1007/s10646-011-0704-3.

56. Querino RB, Zucchi RA. An illustrated key to the species of Trichogramma (Hymenoptera: Trichogrammatidae) of Brazil. Zootaxa. 2005;1073:37-60.

http://dx.doi.org/10.11646/zootaxa.1073.1.3.

57. Khan MS, Farid A, Ullah F, et al. Effect of host and parasitoid density on parasitism efficiency of Trichogramma chilonis (Ishii). Asian J Plant Sci. 2004;3:647-50.

https://doi.org/10.3923/ajps.2004.647.650.

58. Querino RB, Zucchi RA. Redescription of Trichogrammatoidea annulata de Santis (Hymenoptera: Trichogrammatidae). Zootaxa. 2014;677:1-7. http://dx.doi.org/10.5281/zenodo.158556.

59. Nava DE, Takahashi KM, Parra JRP. Trichogramma and Trichogrammatoidea strains to control Stenoma catenifer. Pesqui Agropecu Bras. 2007;42:9-16. https://doi.org/10.1590/S0100204X2007000100002.

60. de Menezes CWG, Soares MA, Fonseca AJ, et al. Palmistichus elaeisis (Hymenoptera: Eulophidae) as an indicator of toxicity of herbicides registered for corn in Brazil. Chil J Agr Res. 2014;74:361-5. http://dx.doi.org/10.4067/S0718-58392014000300016.

61. :Article number

https://doi.org/10.1038/s41598-017-10462-3

de la Cruz RA, Zanuncio JC, Lacerda MC, et al. Side-effects of pesticides on the generalist endoparasitoid Palmistichus elaeisis (Hymenoptera: Eulophidae). Sci Rep. 2017;7:Article number: 10064. https://doi.org/10.1038/s41598-017-10462-3.

62. Paes JPP, Lima VLS, Pratissoli D, et al. Selection of parasitoids of the genus Trichogramma (Hymenoptera: Trichogrammatidae) and parasitism at different eggs ages of Duponchelia fovealis (Lepidoptera: Crambidae). Acta Sci Biol Sci. 2018;40:e42216. https://doi.org/10.4025/actascibiolsci.v40i1.42216.

63. da Silva RB, Cruz I, Figueiredo M, de LC, et al. Development and reproduction of Olla v-nigrum (Coleoptera: Coccinellidae) fed Anagasta kuehniella (Lepidoptera: Pyralidae) eggs supplemented with an artificial diet. Fla Entomol. 2013;96:850-8. https://doi.org/10.1653/024.096.0319.

64. Tavares W, de S, Cruz, da Silva I. RB, et al. Prey consumption and development of Chrysoperla externa (Neuroptera: Chrysopidae) on Spodoptera frugiperda (Lepidoptera: Noctuidae) eggs and larvae and Anagasta kuehniella (Lepidoptera: Pyralidae) eggs. Maydica. 2011;56:283-9. 
65. Tavares W, de S, Tavares, AS de C, Pereira Al de. A, et al. Handicraft using corn ear husk and pest damage affecting its production. Maydica. 2016;61:1-9.

66. Manzoni CG, Grützmacher AD, Giolo FP, et al. Side-effects of pesticides used in integrated production of apples to parasitoids of Trichogramma pretiosum Riley and Trichogramma atopovirilia Oatman \& Platner (Hymenoptera: Trichogrammatidae) BioAssay. 2007;2:1-11. https://doi.org/10.14295/BA.v2.0.50.

67. Morandi Filho WJ, Müller C, de Lima CAB, et al. Evaluation of methodologies for testings the selection of products that regulate the growth of Trichogramma pretiosum (Riley, 1879) (Hymenoptera: Trichogrammatidae) in the cultivation of apple in laboratory conditions. Idesia. 2008;26:78-85. http://dx.doi.org/10.4067/S0718-34292008000300009.

68. 10.1590/S1516-89132012000200018

Soares MA, Leite GLD, Zanuncio JC, et al. Quality control of Trichogramma atopovilia and Trichogramma pretiosum (Hym.: Trichogrammatidae) adults reared under laboratory conditions. Braz Arch Biol Technol. 2012;55:305-311. http://dx.doi.org/10.1590/S1516-89132012000200018.

69. Viggiani G. New genera, species, and records of Trichogrammatidae (Hymenoptera: Chalcidoidea). Fragm Entomol. 2019;51:161-86. https://doi.org/10.4081/fe.2019.377.

70. Querino RB, Zucchi RA. Annotated checklist and illustrated key to the species of Trichogramma Westwood (Hymenoptera: Trichogrammatidae) from South America. Zootaxa. 2019;4656:201-31. https://doi.org/10.11646/zootaxa.4656.2.1.

71. Carvalho G, dos S, Silva, Veras LB. MS, et al. Biological parameters of three Trichogramma pretiosum strains (Riley, 1879) (Hymenoptera: Trichogrammatidae) on eggs Helicoverpa armigera (Hübner, 1805) (Lepidoptera: Noctuidae). Acta Sci Biol Sci. 2017;39:349-55.

https://doi.org/10.4025/actascibiolsci.v39i3.33426.

72. Carvalho GA, Godoy MS, Parreira DS, et al. Effect of chemical insecticides used in tomato crops on immature Trichogramma pretiosum (Hymenoptera: Trichogrammatidae). Rev Colomb Entomol. 2010;36:10-5.

73. SAEG. (Sistema para Análises Estatísticas), Versão 9.1: Fundação Arthur Bernardes - UFV - Viçosa, 2007.

74. Warton DI, Hui FKC. The arcsine is asinine: the analysis of proportions in ecology. Ecology. 2011;92:3-10. https://doi.org/10.1890/10-0340.1.

75. Tukey J. Comparing individual means in the analysis of variance. Biometrics. 1949;5:99-114. https://doi.org/10.2307/3001913.

\section{Supplementary Files}

This is a list of supplementary files associated with this preprint. Click to download.

- Manuscriptdata.xls 